\title{
The Impact of COVID-19 on Public Space: A Review of the Emerging Questions
}

Jordi Honey-Rosés ${ }^{1 *}$, Isabelle Anguelovski ${ }^{2,3}$, Josep Bohigas ${ }^{4}$, Vincent Chireh $^{5}$, Carolyn Daher ${ }^{6}$, Cecil Konijnendijk $^{7}$, Jill Litt, ${ }^{6}$ Vrushti Mawani $^{1}$, Michael McCall ${ }^{8}$, Arturo Orellana ${ }^{9}$, Emilia Oscilowicz ${ }^{1}$, Ulises Sánchez ${ }^{10}$, Maged Senbel ${ }^{1}$, Xueqi $\operatorname{Tan}^{11}$, Erick Villagomez ${ }^{1}$, Oscar Zapata ${ }^{12}$, Mark Nieuwenhuijsen ${ }^{6}$

\footnotetext{
${ }^{1}$ School of Community and Regional Planning University of British Columbia. 1933 West Mall, Vancouver, BC V6T 1 Z2 Canada.

${ }^{2}$ Institute of Environmental Science and Technology, Universitat Autònoma de Barcelona (ICTA-UAB) Bellaterra, Spain.

${ }^{3}$ Institució Catalana de Recerca i Estudis Avançats (ICREA), Barcelona, Spain.

${ }_{5}^{4}$ Barcelona Regional, C/ 60, 25-27. Edifici Z. Sector A. Zona Franca, 08040 Barcelona, Spain.

${ }^{5}$ Institute for Resources, Environment, and Sustainability, University of British Columbia. 2202 Main Mall, Vancouver, BC V6T 1 Z4 Canada.

${ }^{6}$ IS Global, Institute for Global Health, Doctor Aiguader 88, Barcelona 08003 Spain.

${ }^{7}$ Faculty of Forestry, University of British Columbia. 2424 Main Mall, Vancouver, BC V6T 1Z4, Canada.

${ }^{8}$ Centro de Investigaciones en Geografía Ambiental, Universidad Nacional Autónoma de México, Morelia, Mexico.

${ }^{9}$ Instituto de Estudios Urbanos y Territoriales, Pontificia Universidad Católica de Chile, Santiago, Chile.

${ }^{10}$ Independent Consultant, Morelia, Mexico.

${ }^{11}$ School of Humanities, Southeast University. No. 2, Southeast University Road, Jiangning District, Nanjing, 211189, China.

${ }^{12}$ Department of Economics, University of Regina. 3737 Wascana Parkway, Regina, SK S4S OA2 Canada.

*Corresponding Author: jhoney@mail.ubc.ca
}

\begin{abstract}
Restrictions on the use of public space and social distancing have been key policy measures to reduce the transmission of SAR-CoV-2 and protect public health. At the time of writing, one half of the world's population has been asked to stay home and avoid many public places. What will be the long term impacts of the COVID-19 pandemic on public space once the restrictions have been lifted? The depth and extent of transformation is unclear, especially as it relates to the future design, use and perceptions of public space. This article aims to highlight emerging questions at the interface of COVID-19 and city design. It is possible that the COVID-19 crisis may fundamentally change our relationship with public space. In the ensuing months and years, it will be critical to study and measure these changes in order to inform urban planning and design in a post-COVID-19 world.
\end{abstract}

Keywords: COVID-19, Design, Planning, Public space.

Citation

Honey-Roses, J., Anguelovski, I., Bohigas, J., Chireh, V., Daher, C., Konijnendijk, C., ... Nieuwenhuijsen, M. (2020, April 21). The Impact of COVID-19 on Public Space: A Review of the Emerging Questions. https://doi.org/10.31219/osf.io/rf7xa 


\section{Introduction}

Restrictions on the use of public space, confinement and social distancing have been key policy measures to reduce transmission of SAR-CoV-2 and protect public health. We are currently in the midst of unprecedented restrictions in the use of public spaces worldwide. Half of the world's population has been asked to stay at home or restrict movement in public (Sandford, 2020). Most people are complying with public health recommendations as evident in the striking images of empty city streets, parks, beaches, plazas and promenades. Cities well-known for their active street life such as New York, Rome or Barcelona now appear ghostly as city-dwellers stay home for the collective public good.

In the midst of the COVID-19 crisis, we feel the sting of having lost our familiar, vibrant, social and lively public places. We write from different locations ${ }^{1}$ where the pandemic is in different phases and our respective cities have implemented different measures: full lockdown; recommended stay at home measures, and one co-author is in Wuhan where public space is re-opening. While some are us are prohibited from being in public unless performing an essential service, others are able to enjoy some parks and green areas. Despite these different experiences, we share an uncertainty about what lies ahead and fear that our sense of place and space may be permanently transformed. When we venture outside our homes, we observe unfamiliar and distant social interactions, raising questions about how social relations in public spaces may be changing.

Planners, designers, architects, landscape managers and journalists are already writing about how this crisis will transform our relationship with public space (Alter, 2020; Florida, 2020; Null and Smith, 2020; Roberts, 2020; van der Berg, 2020). We are still in the early stages of the crisis and it is likely we will be adapting to an evolving global pandemic in the next eighteen months. It will still be weeks until many of us will be able to return to our public spaces, but it is not too early to think about how our professions may have changed or need to adapt.

There is great uncertainty about how COVID-19 will impact future public space design, use and perceptions. How will our relationship with public space change? How long will the changes endure? What is the relationship between public space design and disease transmission? Will the new social behaviours we observe today remain or be ephemeral? Will people's emotional connections with places change? How will the benefits we derive from urban nature change? Will the pandemic teach us new lessons to incorporate into our street designs? Is the attention devoted to COVID-19 distracting us from the existential challenges of sustainability and climate change? Or, optimistically, will this global experience lead us to rethink the way we develop and (re)design our cities?

Many scholars and public observers are weighing in on these important questions (Florida, 2020; Markusen, 2020; Roberts, 2020). The contours of this debate are just beginning to emerge. This article aims to summarize preliminary research questions, ideas and conjectures about how the COVID-19 crisis might change our relationship with public space. We recognize the great uncertainty associated with the ideas put forward. The author Eugene lonesco once said "You can only predict things after they have happened". Nevertheless, our focus is on what the world might be like once the pandemic has passed and the restrictions on the use of public space and social distancing policies have been lifted. We understand that cities may go through more than one peak of the virus outbreak, thereby producing an extended period of social distancing (Kissler et al., 2020). This paper

\footnotetext{
${ }^{1}$ This article has been produced by co-authors located in Ahmedabad (India), Barcelona (Spain), Morelia (Mexico), Regina (Canada), Santiago (Chile), Vancouver (Canada) and Wuhan (China).
} 
tries to think beyond the current measures to consider which changes will stay with us once the immediacy of the pandemic has passed.

As co-authors, we do not necessarily agree on what the future may hold, nor is consensus our aim. Rather, we aim to raise the critical new questions that have emerged as a result of our current global health crisis in order to guide future research and policy.

\section{Will the impact on public space be transformational?}

The size, scope and speed of the crisis make it feel like we are living through a profound transformation. It is as if we are experiencing a tectonic shift, where the ground is moving beneath us, changing the fundamental principles and rules that have governed our practice. Periods of stability can be interrupted by sudden breaks with rapid change. Evolutionary biologists refer to the theory of punctuated equilibrium, in which evolutionary changes are not cumulative and gradual, but rather transpire in specific moments (Gould and Eldredge, 1993). Thomas Kuhn conceptualizes these changes as paradigm shifts (Kuhn, 1962). These breaking moments are opportunities to embark on radically new and bold projects. One might conceptualize this moment as a potential counter shock to disaster capitalism (Klein, 2007). These moments re-define what is acceptable or radical, shifting what policy makers call the Overton window (Crabtree, 2020; Lehman, 2019). These periods create opportunities to carry out endeavors previously thought impossible but now are feasible or necessary. When in the midst of this change, which lessons from the past can we still grab onto and what previous understanding must we discard?

It is unclear if the impacts of COVID-19 on public space will be as profound as they are in other aspects of our life (Corbera et al., 2020). In the realm of public space and design, a key question concerns how long these impacts will be felt, and the degree to which they will be transformational. It may take years before we are able to ascertain how the global pandemic has changed the planning and design of public space. Will 2020 define a before and after in planning and design?

Perhaps such predictions are clouded by the immediacy of the moment. Rather than a profound transformation, perhaps the pandemic will merely refine our practices, yet leave our fundamental approaches and values unchanged. Our respective disciplines have already created a deep body of knowledge, understanding and methods for studying public space. COVID-19 is not our first pandemic, nor is this the first time planning and design has focused on improving public health. Improving the sanitary conditions of cities motivated planners, architects and engineers to re-design cities in the late $19^{\text {th }}$ century (Sennett, 2018). Since the 1990s there has been a resurgent interest in work at the nexus of health and urban planning, and the field has become a well-established area of expertise, with an active scholarly community and focused academic journals with strong repute. This field is nourished by scholars from diverse disciplines such as public health, environmental psychology, planning, and landscape architecture. Seen from this perspective, we should be able to build on existing expertise to update our practices and adapt. Better yet, COVID-19 may present an opportunity to integrate a health perspective into planning in new ways.

Many disciplines are likely to refocus their attention on how they interface with public health. But how will these new ideas be integrated into practice? And how might we leverage the crisis to build more just, healthier and greener cities? Below we review the key dimensions of this debate as it refers to public space which we define as a geographical dimension in which there exists free, legal, unbiased access for all (Benn and Gauss, 1983; Carr et al., 1992; Lawrence, 2001).

While there are many potential impacts of COVID-19 on land use, urban density, telecommuting, energy, transportation, retail, and so forth, our focus is on how the current pandemic may change 
public space. Our list of emerging questions is extensive but not exhaustive. We also anticipate circumstances to change between the time of writing and reading. Things are moving fast.

Table 1. Summary of the emerging questions about how the COVID-19 episode may change the design, use, behaviours and perceptions in public space.

Design

1. Will streets be re-designed?

2. Will the pandemic accelerate the mainstreaming of health criteria into the design of public spaces?

3. Will green space planning need new designs, uses and practices?

4. What is the future of large public spaces?

5. Do we need a new typology for public space?

6. Will the temporary transformations seen during the crisis inspire more permanent changes?

7. What will happen to micro-mobility and mobility sharing?

8. What will be the impacts on public transit?

Perceptions, Use and Behaviour

9. Will we observe fewer people in public?

10. Will we change what we do in public?

11. Will our intuitive carrying capacity for public spaces decrease?

12. Will we observe changes in the use and regulation of interior public spaces?

13. Will we experience infringements on civil liberties?

14. Will our perceptions of public space change?

Inequities and Exclusions

15. How will the needs of vulnerable groups such as women, racial minorities, immigrants, low-income residents, the elderly, children and the homeless be accounted for in future public space designs, practices, and rules?

16. Will cities in the Global South attempt to constrain or regulate the informal street economy?

17. Will the pandemic permanently disrupt the interconnected global settlement system?

\section{Emerging questions on the impact of COVID-19 on public space}

\section{Impacts on the Design of Public Space}

\section{Will streets be re-designed?}

Optimists argue that COVID-19 is an opportunity for city planners to liberate more street space for pedestrians and cyclists, moving us closer to greener cities and a low carbon economy (Nieuwenhuijsen, 2020; Roberts, 2020). In the early days of the crisis there was considerable discussion about the need to widen sidewalks and re-design pedestrian crossings in order to meet social distancing recommendations (Alter, 2020). Famously, New York City was talking about making such a move (Bliss, 2020), however Milan appears to be the first to announce permanent changes, with the widening of sidewalks, $35 \mathrm{~km}$ of new bike lanes and the removal of lanes for vehicles (EFE, 
2020). Other cities such as Boston, London, Portland and Vancouver have begun reconfiguring streets to accommodate for more cyclists and pedestrians over longer distances (Hawkins, 2020; Topham, 2020).

Sidewalks in the Global South tend to be crowded, irregular, if they exist at all. Sidewalks are occupied by street vendors, pavement dwellers and a range of informal activities. In India, the social distancing measures announced have meant 'jugaad'2 style appropriations of streets. In efforts to direct social distancing while queuing, sidewalks leading to shops have been marked with yellow circles a meter and a half apart. Cities in both the Global North and South may need to consider adding more space to accommodate for new queuing norms at the entrances of shops, services and public facilities.

It now appears that an extended phase of social distancing will be put into effect once the stay at home measures have been lifted. This period may invite cities to implement low cost and temporary street calming and pedestrianization projects, potentially following principles of tactical urbanism (Lydon and Garcia, 2015). Cities might revisit Barcelona's superblock model, in which vehicular traffic is redirected in and out of the neighbourhood in a U-turn preventing non-residents from traversing a neighbourhood but still allowing local access (Rueda, 2019; Speranza, 2018). Barcelona has already developed several superblocks and has made plans to expand them over the city grid (Zografos et al., 2020).

Streets might need to be re-designed to meet other emerging needs besides social distancing. Online shopping and home food delivery have taken off, creating a huge demand for drop off and delivery space. This increase demand for curb space may force us to re-visit our ideas about curbside street parking, not only to meet new delivery needs, but also to free space for pedestrians.

Any future changes to street design will be politically fraught. Re-designs are contentious and likely to remain so. It also is unclear which cities will be able to act on the re-design ideas being proposed, and if so, how quickly. The space restrictions will not change, and there will still be a competition for right of way. The redesign and repurposing will also still depend on broader challenges such as individual transportation choices and regional transit funding.

\section{Will the pandemic accelerate the mainstreaming of health criteria into the design of public spaces?}

Including health considerations in the design of public space is not new, yet it is far from mainstream (Nieuwenhuijsen and Khreis, 2019; Nieuwenhuijsen, 2016). Other perspectives have had a greater acceptance amongst urban planners and designers, especially participatory approaches (Blancafort and Reus, 2015; Rowe, 2004) and feminist planning (Ortiz Escalante and Gutiérrez Valdivia, 2015). The inclusion of health criteria in public space design is still incipient, even if several authors have worked on tools that may assist planners and designers to conceptualize, design and build with a health perspective (Bird et al., 2018; Public Health Scotland, 2019). It remains to be seen how these ideas are mainstreamed and what physical form they will take.

\footnotetext{
${ }^{2}$ Roughly translated in English as a resourceful, innovative approach of "making do" given the emergent needs and multiple constraints shaping any context. For more on this, see (Roy, 2011)
} 
Street re-designs that free space for pedestrians and active mobility can help meet several public health objectives, notably through physical activity and the reduction of pollution exposure. The health arguments for active mobility have existed for years (Nieuwenhuijsen et al., 2019; Saelens et al., 2003), but have not always received the attention they deserve. In a post-COVID-19 world, will stakeholders take the health arguments in planning more seriously? And most importantly, will they succeed in transforming streets to become healthier, safer, greener and more livable?

\section{Will green space planning need new designs, uses and practices?}

A pivot toward healthy cities is likely to be accompanied by a more serious effort to make cities greener. Yet the pandemic may change the type and distribution of green spaces we want, as well as our expectations about what green spaces should provide. We foresee a greater demand for smaller green spaces or neighbourhood parks which serve as places of refuge from the louder and bustling city. These places of refuge might be preferred whether or not they are green or grey, a small park or an alley.

Our changing preferences and expectations about green spaces may lead to new designs, uses and practices in green space planning. For example, green space designers might need to create more spaces for individualized and introspective use over team sports. Running trails and paths might be widened. And new expectations regarding social distancing may require re-assessing where individuals might be able to exercise within green spaces. We also might need new or expanded exercise infrastructure given that existing green spaces may not be able to absorb the influx of people at the revised levels of appropriate density.

In cities with stay at home orders, we have observed more use of green spaces, especially the small neighbourhood parks, which seem to be undergoing a renaissance (van der Berg, 2020). Will planners begin to prioritize the design of smaller local, neighbourhood green spaces? Cities with an existing decentralized network of small green spaces such as Valencia (Spain) or Nantes (France) will be better prepared to provide easily accessible opportunities for the enjoyment of nature. From a biodiversity perspective, continuous networks of green spaces will still be more valuable than isolated patches (Forman, 1995). Yet a decentralized network of smaller green spaces will make it easier for residents to have their 'daily dose' of nature. Even visual access to nature has been shown to have important physical and mental health benefits (Velarde et al., 2007).

Ample scientific literature has documented the health benefits of green spaces, although there is still work being done to understand the mechanisms and pathways that explain improved health outcomes (Gascon et al., 2015; Rojas-Rueda et al., 2019; van den Bosch and Ode Sang, 2017). Social interactions have been identified as a major pathway in which greenspaces improve health (De Vries et al., 2013; Litt et al., 2015). The degree to which the social pathway is able to generate health benefits in green spaces in the future may need re-consideration or nuancing.

In the aftermath of the crisis, cities may revisit the potential of unused spaces such as brownfield sites and building rooftops. Cities have a staggering amount of rooftops that are underused, poorly equipped and not meeting their full potential. Chicago has led the way (DiNardo, 2019; Francis and Jensen, 2017), and Barcelona has identified thousands of grey rooftops, of which only a few have been converted into rooftop gardens (Sanyé-Mengual et al., 2016). Community gardens also provide an alternative to public parks, and may develop rules on safe distancing. These 
spaces, whether in the sky or on the ground, are likely to receive renewed attention as open air refuges for stress relief, recreation, cultural activities and socialization among tight networks.

\section{What is the future of large public spaces?}

An obvious potential consequence of COVID-19 is a generalized aversion to large crowds. Concerts, cultural events, sporting events, ceremonies, markets and political protests all bring together many people, often in public squares and plazas. In the immediate future, these gatherings will be restricted. But will the public develop a permanent aversion to large public gatherings?

Such a shift could have implications for how we design our cities but also have important cultural and political consequences. Large public spaces have provided citizens with a space to organize, form groups, come together and voice political dissent throughout human history. Consider the Zócalo in Mexico City, Tienanmen in Beijing, Madan in Kiev, Tahrir in Cairo, Gezi Park in Istanbul, among others (Luisa Martin, 2014; Özgen, 2014). Turning our backs to these spaces would debilitate our notion of public space as 'agora' and threaten to restrict opportunities for coming together. Will the social, civic and recreational uses of the public realm need to be rediscovered and reinvigorated?

A permanent aversion to large public gatherings might change how cities are designed. Most cities have at least one large space to accommodate for large gatherings. Designers often intentionally avoid placing benches, fountains or other permanent infrastructure in large squares to allow for these gatherings, even if infrequent. This practice could be reversed, premised on other urban needs, and go largely unnoticed.

On the other hand, a post-COVID-19 world might value these large flexible spaces as assets. Public spaces are a key feature of a resilient city, in part because of their ability to be transformed for emergency health purposes (Polko, 2010). Our current public health emergency has demonstrated the value of flex spaces. Large green spaces and convention centres have been converted into emergency field hospitals in Vancouver, New York, and London (Booth et al., 2020). In India, empty malls are being turned into shelters for migrant workers who are unable to return to their villages. The value of large public spaces may push us toward modular and decentralized designs that permit this flexibility.

How urbanites will respond to large gatherings is likely to depend on contexts, as well as the expectations about future outbreaks. The perceived risks associated with large gatherings are likely to be highly sensitive to cultural norms and heterogeneous across cities and regions. In many cities and cultures, large gatherings are simply too important for a city's identity, culture or economy. Many religious and cultural celebrations have been celebrated for centuries, having survived countless disruptions, droughts, war and unrest. While it might be possible to postpone or delay celebrations and events temporarily, in many circumstances it will be impossible to halt significant religious or cultural gatherings and ceremonies altogether.

\section{Do we need a new typology for public space?}


The pandemic could force planners and designers to create a new vocabulary or typology to describe places in terms of social density, distances, crowding, or public health risks. The pandemic will create a new lens through which to think about public space, and this new conversation will need a new vocabulary to help organize our ideas and analyze spaces.

For green spaces specifically, the pandemic might force us to revisit our existing green space typologies (Cvejić et al., 2015), with local neighbourhood parks, pocket parks, avenues, and informal green spaces getting greater focus (Rupprecht and Byrne, 2014), as larger parks may take on a different function and use. During the pandemic the role of some green spaces clearly changed (Samuelsson et al., 2020). This also implies that typologies should not only focus on the level of the individual green/public space. Ways should be found to include consideration of how individual spaces are part of public space networks with their own specific functionalities. New public space typologies should also consider the temporary uses of green space as illustrated by the temporary hospitals in New York's Central Park.

\section{Will the temporary transformations seen in cities inspire more permanent changes?}

Cities such as Vienna, Boston, Oakland, Philadelphia and Minneapolis have closed roads to give more space to pedestrians and cyclists (Laker, 2020). These temporary road closures and other short-term measures are serving as testing grounds for changes that may eventually become permanent (Bliss, 2020). Bogotá has widened bike lanes and added $76 \mathrm{~km}$ of additional temporary bike lanes in an effort to halt the spread of the virus, and Mexico City has a plan for something similar (Armario, 2020; Null and Smith, 2020; Wray, 2020). Researchers in the United States are building a database of cities that have implemented cycling and pedestrianization projects in response to COVID-19 (Combs, 2020). Some argue that the temporary road closures will serve as a catalyst for embarking on more ambitious projects in pedestrianization and public space enhancement that citizens have demanded for years (Bliss, 2020).

In cities that have been entirely locked down, residents have noticed major reductions in noise and air pollution, and even a return of wildlife (Millan Lombrana and Roston, 2020). Satellite data show massive reductions in air pollution across China as restrictions took effect (NASA, 2020). Given the connection between urban air pollution and early death, the change in air quality might have far-reaching positive effects on health at both ends of the age scale (Null and Smith, 2020). These temporary changes have allowed residents to re-imagine their city as a place that smells better, sounds more peaceful, and permits better sleep.

The urban experiments in pedestrianization and traffic reduction provide a valuable precedent. Yet permanent transformations will still require changes in personal habits, policies, incentives, and infrastructures. Researchers may consider tracking how these experiments have influenced the views and opinions of residents or changed the perceived political feasibility of these initiatives among decision makers. Following up on the long-term impact of the COVID-19 street closures will also help us learn about where and why some of the changes have become adopted. This may also provide a critical learning opportunity for theory development in tactical urbanism (Lydon and Garcia, 2015).

\section{What will happen to micro-mobility and sharing?}


Micro-mobility and sharing activities were booming prior to the pandemic, and their widespread adoption was also leading to major disputes over space on sidewalks, curbs, parks and other urban places (Abend, 2019). Micro-mobility devices have been struggling for space on the streets, competing with pedestrians, bikes and motorized vehicles. As individualized transport, these smaller devices might be welcome in a post-pandemic world and could benefit from street re-designs that allow for wider sidewalks or enlarged cycling lanes. The affordability of these devices may also make them attractive when the economy is in a downturn.

At the same time, the sharing model is likely to be hurt by the pandemic due to the perceived health risk of sharing vehicles with an unknown community. All mobility sharing models (car, bike, scooter) will probably need to invest in regular hygiene and vehicle cleaning. These additional costs may make the financial model unviable for the service provider or generate costs passed onto users. On the other hand, it is possible that users are not dissuaded, and that sharing rebounds after the pandemic as a preferred alternative to public transit.

\section{What will be the impacts on public transit?}

There is serious concern that the public will reject public transportation in favour of private motor vehicles. People are afraid, with good reason, to travel by public transport. A study in Hubei showed COVID-19 spread from one person to nine over the course of a single long-distance bus journey (Null and Smith, 2020). Where there will be a choice, people will prefer to use their own cars, or taxis that are regulated with virus-free drivers and deep cleaning. It would be naïve to predict that people will happily return to public mass transit without major adjustments to vehicle design and operations, as well as infrastructure in public spaces to help prevent the next spread. Busses and trains should carry fewer and more dispersed passengers, public space is needed to disperse the ingress and egress at stations and bus terminals, and installations will need frequent disinfection and cleaning. Steps in this direction can already be seen Wuhan, Kigali, Rome, Milan, Washington DC, Hong Kong, Istanbul and elsewhere (EFE, 2020; Null and Smith, 2020; TUMI, 2020).

The worst case scenarios are that public transit systems bankrupt, they will get little public money support in the near future, more of them are privatized, and the impact on public city space will be deleterious - an increase in private vehicle traffic, congestion, pollution and more social division.

\section{Impacts on Use of Public Space}

\section{Will we observe fewer people in public?}

When the pandemic is over, will people flee from public spaces or flock to them? In terms of total use of public space, what spatial and temporal patterns might we observe? One would expect very different responses in each city, space or context. Public life studies often count people in streets, parks or squares in order to assess use patterns and evaluate how the site is functioning (Akaltin et al., 2019; Anderson et al., 2018; City of Vancouver, 2018). The Gehl Institute has developed a detailed protocol for counting people staying or moving through public places (Gehl Institute, 2017) and cities compare themselves based on these metrics as they can also be indicators of a space's success (Gehl, 2013; Gehl and Svarre, 2013). Often, the presence of people in a space 
is interpreted as indicative that a public space is functioning and healthy (Sadik-Kahn and Solomonow, 2017). Professional planners speak of "sticky streets" where people stay and linger (Toderian, 2014). Downtown associations and retailers count pedestrian traffic in order to estimate potential rents for commercial real estate or to project retail revenue. The scholarly work on pedestrian measurement and modelling (Hankey et al., 2012; Ryus et al., 2016) may undergo a major upheaval following the pandemic. In some cities, the pandemic may show a break from the past, and pedestrian models that rely on past data might need re-calibration. In a post-COVID-19 world, how might we change how we interpret data on public life?

We might also expect changes in the temporal patterns and spacing of users over the day, as people try to avoid peak hours. Once again, it is unclear if the short term changes observed in recent days will persist, implying that we are experiencing a fundamental shift in the patterns of public use. To answer this question researchers might rely on digital data sources collected by mobile devices and sensors in the built environment which are "always on" and capture ongoing changes (Salganik, 2019). Such data collection devices may be used for a variety of purposes including government surveillance, raising legal and ethical questions.

The pandemic may also reinforce social and class differences in the use of public space. Lower income households are more likely to be travelling in the city or attending to the public because of employment obligations. In the United States, geospatial data has shown that lowerincome workers continued to move around in the midst of the pandemic, while higher income workers were more likely to work from home (Valentino-DeVries et al., 2020). Skilled workers in the knowledge economy can more easily shift to online and distance working, thereby minimizing exposure. Lower income workers may not have this choice.

If this tele-working model becomes more entrenched, it could change who is using which public spaces and further exacerbate social divisions. Knowledge economy workers will make more use of parks, promenades and green spaces, whilst those who cannot work from home will be more exposed working in public spaces, streets, public transit, etc. Some public spaces may cease to be places for social mixing by class, education level or income. The structural production of spatial segregation in public spaces creates political and moral dilemmas for future design and investment in urban space. Judging from the history of public urban investment allocations, it is easy to imagine where future improvements will be made.

\section{Will we change what we do in public?}

The modern notion of public space was born in the 19th century when city dwellers strolled the boulevards of Paris, London, or Barcelona (Solà-Morales, 2008). Those who walked the wide streets were captivated by the beautiful window displays, as the emerging consumer culture contributed to the development of public space. At the same time, early window shoppers were aware of each other. They came outside to see and be seen (Sennett, 2018). These two early activities in public space, shopping and socializing, are precisely the activities that are most likely to be impacted by COVID-19. In other words, COVID-19 is challenging the two activities that brought people out into the city the first place, when the very idea of public space was born.

The concern that online shopping may decimate brick and mortar stores is a topic that will receive ample attention by other authors, and they will do more justice to this issue than we can. 
Here we merely emphasize that COVID-19 is likely to produce a drop in pedestrian traffic associated with commercial activity, and that this reduced pedestrian traffic will have negative multiplier effects on many local stores, coffee shops and retailers, which ultimately will threaten to change neighbourhoods.

Our social behavior in public may also change. The pandemic may limit our ability to develop new relationships, especially among strangers. Public space might still be a place for social interaction, but it may be more difficult for the spontaneous and informal. These forms of exchange are often needed to build community. To understand the impacts of COVID-19 on socialization and informal social interactions, we will need observational and qualitative field work once the restrictions have been raised. It may also be useful to re-visit past public life studies that collected data on average group size in public to document any changes.

Cities that rely on tourism are likely to notice significant reconfiguration of street activities, especially near major attractions or on streets that rely on foot traffic from visitors. The look and feel of these highly visited cities will change, at least for a while. In China there are signs that in some cases, tourism can rebound. During the Qingming Holiday in early April 2020, an estimated 20,000 tourists wearing protective face masks crowded the mountain trails of Huangshan (Hardiman, 2020).

\section{Will our intuitive carrying capacity for public spaces decrease?}

The esteemed observer of public life William Whyte proposed that spaces appear to have a natural carrying capacity (Whyte, 1980). He observed that individuals would cluster on the steps outside of office buildings in New York City, and the total number of people would hover around a certain maximum, not necessarily at capacity, but close. He hypothesized that each space had a carrying capacity, and individuals would intuitively not stay in the space if the area was close to capacity. He suggested that each of us have an intuitive feeling about what "too many" looks. This hypothesis suggests that the COVID-19 crisis may alter our intuitive sense of what the "right" number of people is for a particular space.

\section{Will we observe changes in the use and regulation of interior public spaces?}

Interior spaces, exterior spaces and public space are closely related. Many older cities invest heavily in public space precisely because the living quarters in homes are more cramped, smaller, and darker. How will the pandemic change the relationship between interior and exterior spaces? The stay at home measures, and lockdowns in particular, have already shattered traditional use designations inside our homes. Those of us confined to small apartments, especially with young children, have entirely transformed our home interiors. A kitchen is no longer merely a place for cooking and a bedroom is no longer a place for resting. We have discovered new corners and functions for small spaces, walls, ceilings, windows and balconies. Confinement has led to multifunctionality, creativity, fluidity and adaptation (Rosel, 2020).

Fears of contagion in closed indoor spaces may increase demand for more exterior spaces and improved ventilation. COVID-19 may provide particular challenges for the design of libraries, government office buildings, waiting rooms, schools, or other public services, which might need more exterior spaces and more ventilation. Service industries and restaurants might need to reorganize 
themselves to accommodate for more outdoor spaces where the risk of transmission is lower, or locate fewer tables located further apart.

Interior spaces are heavily regulated by many codes and laws, and like all regulatory systems, the rules are contextual and value-laden. To date, interiors have been largely shaped by minimum distances. Common minimum distances include those for residential hallways, corridors, or distances between urinals, and dimensions between seats in classrooms. Most of these are significantly smaller than the recommended COVID-19 "social distances". As such, any radical changes to interior environments over the short term seems unlikely.

If, over the long-term, there was a decision to enact changes to regulations governing interiors that are more in line with recommended "social distances", the consequences would be much larger than envisioned at first sight. The dimensions of buildings and their associated footprints would grow considerably, since regulatory minimums are typically used for the most common everyday spaces within buildings. The effects of this would be heavily felt across the urban landscape space, as urban densities will have to raise to accommodate an additional 2.5 billion urban dwellers by 2050 (van den Berg 2020). For example, one can easily foresee city-scale regulations responding to the additional space requirements for higher interior minimums with higher floor space allowances, meaning higher buildings. As such, any changes to regulatory minimums required for interiors must ultimately be weighed against its systemic impacts on city building and design across scales.

\section{Will we experience infringements on civil liberties?}

Surveillance systems, tracking technology and restrictions in movement were essential strategies that have allowed governments to slow down the outbreak (WHO, 2020). Surveillance technologies may also play a role in the deconfinement process, and provide health officials with our digital traces to identify contacts among individuals who have tested positive for COVID-19.

China is implementing sophisticated tracking methods, and the post-lockdown procedures in Wuhan may be a preview for what is to come. The current strategy has prioritized tracking potential infections, and this has come with control measures and health checkpoints at the entrances and exits of most public places including subway stations, parks, and markets. Officials check for the mandatory use of face masks, conduct a body temperature check and verify an individualized QR health code. The QR health code is obtained online from the health authorities following a background check and verification. The code serves as an electronic voucher for individuals to enter and exit buildings, spaces or city areas. Citizens are also required to scan a QR code upon their arrival and departure from large indoor shopping malls, supermarkets and subway stations.

Private companies and governments in the UK, United States, Germany, Ireland, and Singapore are also building apps to track infections. These systems may produce interactive maps with government health data showing the locations where infected people have visited and who they have contacted. A more intrusive systems being developed by an Apple-Google collaboration geolocates all its users - nothing new here -, but when a user has developed symptoms or tested positive for COVID-19, then that user's location is Bluetooth'ed to all app-enabled phones (c. $9 \mathrm{~m}$ range) for a number of days (The Economist, 2020). South Korea has a very effective tracking system which does not yet use phone apps but relies on intensive detective follow up on people 
identified as infected. It involves data from in-depth interviews, CCTV, credit card expenditures, etc. All the spatial data on people's movements in public spaces are then publicly released to help identify potential contactees (Kim, 2020).

However it is notable that there seems to be user-resistance to this monitoring. Even in Singapore, only $1 / 6^{\text {th }}$ of a normally compliant population had taken up the Government's contacttracing app, TraceTogether after a month; and only $40 \%$ of Icelanders were using Ranking C-19, the most extensive contact-tracing app in the world (The Economist, 2020).

The crisis may be used to crackdown on a range of civil liberties of Freedom of Peaceful Assembly (Article 20, Universal Declaration of Human Rights; also the European Convention on Human Rights), as well as the freedom of movement by preventing large gatherings. The restriction of movement may be an effective strategy to reduce disease transmission, however these controls may also be used to deny opportunities for mass gatherings and suppress political opposition, as recently seen in oppressive actions in Spain, Hungary, Brazil, Hong Kong and elsewhere (Amnesty International, 2019; Brannen, 2020; CELAG, 2020; UNOHCR, 2020).

Our awareness of surveillance and tracking efforts might itself contribute to changes in mobility patterns, - a type of spatial-Hawthorne effect for movement in public space. To avoid being tracked, some might choose to leave their devices at home. For racialized minorities and immigrants, the use of surveillance methods might create new fears of control, restrictions, and arrests, thus discouraging their presence in public.

\section{Will our perceptions of public spaces change?}

Urban designers aim to create places where people feel welcome, comfortable and safe. Perceptions of public space are an important field of research (Heffernan et al., 2014; Pugalis, 2009) and public perceptions may dictate what is designed and how. However the current pandemic threatens to profoundly change our relationship with these spaces, especially when other people are present.

There are questions concerning the effect of lockdown and stay at home measures on children and youth, and how this experience may change their sense of attachment and intimacy with public places. Not generic public space, but the city places previously associated with their emotions and feelings, such as squares, parks, alleys, river fronts - places where people may have had romantic or cultural experiences. Youth might become less attached to these places as a result of the prolonged absences, or might grow more accustomed to online isolation.

More optimistically, those who have lived through severe confinement or lockdown may have a renewed appreciation of parks and plazas, although this may not be the case for everyone. There are likely to be heterogeneous effects by individuals, and perhaps gender and age, and other dimensions. We can also expect large variation by city, country or region. It is also possible that the changes in perceptions will correlate with the severity in which COVID-19 impacted a city, the severity of the lockdown measures during the crisis, the economic impact on the household, among other correlates. 
COVID-19 has motivated health authorities in Latin America to restrict access to large shopping areas and malls. For high-income families, this has forced a change in consumption habits and obliged some consumers to venture into less familiar neighbourhoods. The pandemic may generate new patterns and configurations of use, potentially reshaping public space in Latin American cities. While certain public spaces might become more valued, the restrictions may also increase perceptions of insecurity, - an issue that strongly dictates use (or lack thereof) of public space in Latin America.

\section{Inequities and Exclusions}

\section{How will the needs of vulnerable groups such as women, racial minorities, immigrants, low-income residents, children, youth, the elderly, and the homeless be accounted for in future public space designs, practices, and rules?}

COVID-19 is already exacerbating existing inequalities (Kluth, 2020). Racial minorities, the homeless, and poorer neighbourhoods are being harder hit by COVID-19 because they have less access to health care and more difficulties self-isolating (Du et al., 2020). These racial, class and neighbourhood inequities may bleed over into the public realm. For instance, vulnerable groups tend to have less access to green spaces, public or private. Furthermore, green spaces in lower-income neighborhoods are often smaller, under-maintained, and less numerous than those in wealthier neighborhoods (Dahmann et al., 2010; Heynen et al., 2006). COVID-19 may also accelerate the privatization of public space, either through the physical closure of streets or parks, thereby producing more gated communities and neighborhoods.

Public spaces serve a variety of purposes for different demographics and are particularly important for socially vulnerable residents (Anguelovski, 2020). Public spaces are often the only recreational outdoor spaces for low-income residents and can provide relief from cramped living conditions. Public spaces are particularly important for children and youth (Christian et. al. 2015). For seniors living alone, public spaces provide social interactions that mitigate isolation and loneliness.

Women have been impacted by lockdowns and stay at home orders. In the UK, phone calls to domestic abuse helplines have jumped $700 \%$; in Spain, domestic abuse reports went up $18 \%$ in the first two weeks of COVID-19 lockdown; with similar patterns seen in Italy, France, China, Mexico, and the United States (Felbab-Brown, 2020; Townsend, 2020). Women and others in abusive relationships are forced to spend time with their abusers, unable to take refuge in community spaces.

Undocumented immigrants and racialized minorities might avoid public spaces in the future if they are more controlled, patrolled and "securitized". Homeless residents may feel the same pressures. On the other hand, if public spaces become more secured by the police and other public agents, criminal activities might decrease, allowing others to use those spaces again.

The neoliberal urban policies in Latin America have produced segregated and fragmented cities (Carrión and Dammert-Guardia, 2019), with important differences in the quantity and quality of public spaces between high and low income neighbourhoods (Vicuña et al., 2019). The limited quality of public spaces in lower income neighborhoods is compounded by the absence of safety and security, as criminal groups have taken functional control of these spaces. In Chile, Venezuela, 
Turkey, Iran, Hungary and elsewhere, the pandemic has led authorities to re-assert control of the streets to enforce the quarantine and restrict movement, thereby making these spaces safer for health workers or essential services, but unusable for the general public, especially for protest. This raises new questions with regard to the advisability of police-based, militarized and surveillance approaches to ensuring safety in city spaces (Luneke, 2015). Our current condition is creating a powerful precedent, and public opinion is likely to be divided on how much of a police-state we are willing to accept in exchange for safer cities. The risk is that the formulation of new surveillancebased and policed spaces will deepen patterns of segregation and fragmentation of the Latin American city.

Religious minorities may experience further discrimination in public space as associations are made between class, religion, and the spread of disease. In India, for instance, the media linked the spread of COVID-19 to a Muslim gathering in New Delhi. As a result, Muslims in public spaces, as well as Muslim public spaces are viewed even more suspiciously than before (Ellis-Petersen and Rahman, 2020).

\section{Will cities in the Global South aim to constrain or regulate the informal street economy?}

The hum and shouts of street vendors is a vital part of the economic and social life of many cities and towns in the Global South (Brown et al., 2010; Janoschka and Sequera, 2016). Millions of households depend on the informal economy that unfolds in public space (International Labour Organisation, 2018). In Mexico alone, 31.3 million people work in the informal sector, representing over half of its working population (INEGI, 2020). How will these informal sellers adapt to any long term changes in public space, regulations, restrictions, or changing cultural norms? In the short term, many street vendors are already forced to decide between the risk of illness or the risk not being able to provide for their families. What response, resistance or re-organization might we see in street vendor communities in the Global South?

The pandemic is likely to push street vendors and other informal workers into a long term economic recession. In Bangkok, for example, earnings of street vendors are down $80 \%$ since implementation of a mandatory lockdown by the Thai government (Taylor et. al. 2020). Consumers may increasingly walk away, as bustling outdoor street markets may be seen as hazards or sources of contamination (Wertheim-Heck, 2020).

The state of emergency in Latin American countries is severely impacting the informal economy, where this sector represents between 30 and $40 \%$ of the workforce. The situation is especially difficult in Colombia, Peru, Chile, and Ecuador that have received a large influx of undocumented workers, many from Venezuela, who are a large proportion of informal street workers. With a weak welfare state, workers are unprotected, ignored and vulnerable to sanctions or unfair treatment (Schlack Fuhrmann et al., 2018; Vaccotti, 2017). The situation risks generating a situation of profound humanitarian crisis and massive political unrest (Kluth, 2020).

How will governments engage with the informal sector working in the streets? How feasible is it to restrict these activities when so many families rely on street trade for their livelihoods? For now, the regulation of the informal economy in public space appears to face the same challenges as before 
COVID-19 -- the system is complex, poorly documented and with little data to understand its true dimensions. As a result, it may be impossible to regulate or restrict regulations or improve the economic situation for such vulnerable informal workers, even after the pandemic mandates have been lifted.

\section{Will the pandemic permanently disrupt the interconnected global settlement system?}

While other disciplines have developed global regulatory systems, work at such scale has not been seriously considered in urbanism. Does this crisis open the door for regulating the movement of individuals based on city or region of origin? Will the decisions of cities ripple out with global consequences faster than even before? In a time of global interconnection where a relatively localized regulatory decision can have global ramifications, is it necessary to start thinking about urban-scale regulations at a global scale? Until now, this idea has hardly been taken seriously by urbanists, with a few exceptions.

Constantinos Doxiadis predicted this conundrum 50 years ago with his writing on the Ecumenopolis, which he believed was the inevitable trajectory of the human settlements given technological and socio-economic evolution (Doxiadēs et al., 1974; Villagomez, 2018). Many thought this idea of a global city was a far flung idea at the time. Yet, five decades later, we are now dealing with what he foresaw: an interconnected global settlement system so intimately connected that it is virtually impossible to draw clear boundaries between settlements around the world.

\section{Conclusion}

We review how our current COVID-19 public health crisis may change public space design, perceptions and use and management. The impacts are likely to vary by city and within them. Rather than taking strong positions on these questions, we see this as the time to identify the uncertainties and range of outcomes.

It has become cliché to claim that this crisis is an opportunity, and yet never before has so much attention been devoted to cities and health, making this is an unprecedented opportunity to examine the links between urban planning, public space and wellbeing. Our future city is not preordained, but will be the result of specific decisions about public space. We hope public spaces will remain a valued place for socialization, community building, and identity formation in a post-COVID world. Given the transformation we are witnessing, in the ensuing months it will be critical to measure the changes in use and perceptions of public spaces in order to inform urban planning and design.

Addressing the COVID-19 crisis will also require rethinking how public space design can protect and promote planetary health. This can only be achieved with active communities of practice. Planning and public health professionals must come together to build healthier cities during this crisis and beyond. 


\section{Acknowledgements}

JHR would like to thank Sara, Lila and Maia for allowing this paper to be written during our lockdown in Barcelona where we sat on the balcony wishing for a return to our favourite public spaces.

\section{References}

Abend, L., 2019. Cyclists and E-Scooters are clashing in the battle for Europe's streets. Time Magazine.

Akaltin, D., Chen, J., Cho, W., De Haan Bosch, C., Flock, I., Grondin, S., Guzmán, I., King, S., Kinman, A., McCausland, S., Oscilowicz, E., Rachelson, H., Roe, J., Soler Cruz, J., Yilang, Y., Zhu, J., Muxi, Z., Honey-Rosés, J., 2019. Life in Poblenou: Observing Spaces in Transition. Vancouver, Canada.

Alter, L., 2020. Urban design after the coronavirus [WWW Document]. Treehugger. URL https://www.treehugger.com/urban-design/urban-design-after-coronavirus.html (accessed 4.9.20).

Amnesty International, 2019. Spain's conviction for sedition of Jordi Sánchez and Jordi Cuixart threatens rights to freedom of expression and peaceful assembly [WWW Document]. Spain: Analysis of the Supreme Court's ruling in the case of Catalan Leaders. URL https://www.amnesty.org/en/latest/news/2019/11/spain-conviction-for-sedition-of-jordisanchez-and-jordi-cuixart-threatens-rights-to-freedom-of-expression-and-peaceful-assembly/

Anderson, R., Chin, S., Dara, N., Harlos, D., Johnson, E., Labahn, S., LaRocque, E., Lloyd, G., Lone, S., McBurnie, M., Nakao, T., Nesbitt, C., Oswald, T., Raphael, L., Shen, H., van der Veen, A., Zhou, S., Villagomez, E., Honey-Rosés, J., 2018. Life in Poblenou: Observation and Exploration.

Anguelovski, I., 2020. Expanding the boundaries of justice in urban greening scholarship: Towards an emancipatory, antisubordination, intersectional, and relational approach. Annals of the American Association of Geographers 1-59.

Armario, C., 2020. Bogotá Encourages Bicycle Use to Prevent COVID-19 - San Diego Union-Tribune en Español. Associated Press.

Benn, S., Gauss, G., 1983. The public and the private, in: Public and Private in Social Life. St. Martin's Press, New York, pp. 3-30.

Bird, E.L., Ige, J.O., Pilkington, P., Pinto, A., Petrokofsky, C., Burgess-Allen, J., 2018. Built and natural environment planning principles for promoting health: An umbrella review. BMC Public Health 18, 1-13. doi:10.1186/s12889-0185870-2

Blancafort, J., Reus, P., 2015. Pioneros de la participación colectiva en los procesos de planificación urbana. Legado Halprin. Architecture, City and Environment 10, 57-76. doi:10.5821/ace.10.28.3681

Bliss, L., 2020. Mapping How Cities Are Reclaiming Street Space [WWW Document]. CityLab. URL https://www.citylab.com/transportation/2020/04/coronavirus-city-street-public-transit-bike-lanes-covid-19/609190/ (accessed 4.8.20).

Booth, W., Spolar, C., Rolfe, P., 2020. Vast coronavirus 'field hospitals" fill spaces that hosted wedding expos and dog shows - The Washington Post.' The Washington Post.

Brannen, S., 2020. Will Covid-19 End the Age of Mass Protests? Center for Strategic \& International Studies.

Brown, A., Lyons, M., Dankoco, I., 2010. Street traders and the emerging space for urban voice and citizenship in African cities. Urban Studies 47, 666-683.

Carr, S., Francis, M., Rivlin, L., Stone, A., 1992. Public Space: Environment and behavior. Cambridge University Press, Cambridge, UK.

Carrión, F., Dammert-Guardia, M., 2019. Derecho a la Ciudad: una evocación de las transformaciones urbanas en América Latina. IFEA, CLACSO, FLACSO, Lima.

Casanovas, R., Ciocoletto, A., Fonseca Salinas, M., Gutiérrez Valdivia, B., Muxí, Z., Ortiz Escalante, S., 2014. Mujeres Trabajando. Guía de reconocimiento urbano con perspectiva de género. Col.lectiu Punt 6 Comanegra, Barcelona.

CELAG, 2020. Geografía política del coronavirus en América Latina. Análisis Político. CELAG.

City of Vancouver, 2018. Downtown Vancouver Public Space and Public Life Study. Vancouver.

Combs, T., 2020. Local Actions to Support Walking and Cycling During Social Distancing Dataset [WWW Document]. Pedestrian and Bicycle Information Centre. URL http://pedbikeinfo.org/resources/resources_details.cfm?id=5209

Corbera, E., Anguelovski, I., Honey-Rosés, J., Ruiz-Mallén, I., 2020. Academia in the Time of COVID-19: Developing an Ethics of Care. Planning Theory \& Practice. doi:10.1080/14649357.2020.1757891

Crabtree, J., 2020. Optimisim in the time of Coronavirus [WWW Document]. Notes \& Writing: 5 Reasons to be Cheerful. URL jamescrabtree.com (accessed 3.22.20).

Cvejić, R., Eler, K., Pintar, M., Železnikar, Š., Haase, D., Kabisch, N., Strohbach, M., 2015. A Typology of Urban Green Spaces , Ecosystem Provisioning Services and Demands.

Dahmann, N., Wolch, J., Joassart-Marcelli, P., Reynolds, K., Jerrett, M., 2010. The active city? Disparities in provision of urban public recreation resources. Health \& Place 16, 431-445. doi:https://doi.org/10.1016/j.healthplace.2009.11.005

De Vries, S., van Dillen, S.M.E., Groenewegen, P.P., Spreeuwenberg, P., 2013. Streetscape greenery and health: Stress, social cohesion and physical activity as mediators. Social Science and Medicine 94, 26-33. doi:10.1016/j.socscimed.2013.06.030

Doxiadēs, K.A., Papaiōannou, J.G., Athēnaïko Kentro Oikistikēs., 1974. Ecumenopolis : the inevitable city of the future. Norton.

Du, J., King, R., Chanchani, R., 2020. Tackling Inequality in Cities is Essential for Fighting COVID-19. World Resources 
Institute.

Elliott, D.L., 2008. A better way to zone : ten principles to create more livable cities, Island Press.

Ellis-Petersen, H., Rahman, S.A., 2020. Coronavirus conspiracy theories targeting Muslims spread in India | World news | The Guardian. The Guardian.

Felbab-Brown, V., 2020. COVID-19 can augment violence to Mexican women. Bookings Institute.

Florida, R., 2020. We'll Need To Reopen Our Cities. But Not Without Making Changes First. CityLab.

Forman, R.T.T., 1995. Land Mosaics: The Ecology of Landscapes and Regions. Cambridge University Press, Cambridge, United Kingdom.

Francis, L.., Jensen, M., 2017. Benefits of green roofs: A systmatic review of the evidence for three ecosystem services. Urban Forestry \& Urban Greening 28, 167-176.

Gascon, M., Mas, M.T., Martínez, D., Dadvand, P., Forns, J., Plasència, A., Nieuwenhuijsen, M.J., 2015. Mental health benefits of long-term exposure to residential green and blue spaces: A systematic review. International Journal of Environmental Research and Public Health 12, 4354-4379. doi:10.3390/ijerph120404354

Gehl, J., 2013. Cities for people. Island Press.

Gehl, J., Svarre, B., 2013. How To Study Public Life, How To Study Public Life. Island Press, Washington DC. doi:10.5822/978-1-61091-525-0_1

Gould, S. jay, Eldredge, N., 1993. Punctuated equilibrium comes of age. Nature 366, 223-227. doi:10.1038/366223a0

Hankey, S., Lindsey, G., Wang, X., Borah, J., Hoff, K., Utecht, B., Xu, Z., 2012. Estimating use of non-motorized infrastructure: Models of bicycle and pedestrian traffic in Minneapolis, MN. Landscape and Urban Planning 107, 307316. doi:10.1016/j.landurbplan.2012.06.005

Hawkins, A.J., 2020. There's no better time for cities to take space away from cars. Verge.

Heffernan, E., Heffernan, T., Pan, W., 2014. The relationship between the quality of active frontages and public perceptions of public spaces. Urban Design International 19, 92-102. doi:10.1057/udi.2013.16

Heynen, N., Perkins, H.A., Roy, P., 2006. The Political Ecology of Uneven Urban Green Space: The Impact of Political Economy on Race and Ethnicity in Producing Environmental Inequality in Milwaukee. Urban Affairs Review $42,3-25$. doi:10.1177/1078087406290729

INEGI, 2020. Resultados de la Encuesta Nacional de Ocupación y Empleo. Cifras durante el cuarto trimestre de 2019. Mexico. Mexico.

International Labour Organisation, 2018. World Employment and Social Outlook: Trends 2018, International Labour Organization.

Janoschka, M., Sequera, J., 2016. Gentrification in Latin America: addressing the politics and geographies of displacement. Urban Geography 37, 1175-1194. doi:10.1080/02723638.2015.1103995

Kim, M.S., 2020. Seoul's Radical Experiment in Digital Contact Tracing. In South Korea, the government is disseminating detailed tracking data on people with COVID-19. The New York.

Kissler, S.M., Tedijanto, C., Goldstein, E., Grad, Y.H., Lipsitch, M., 2020. Projecting the transmission dynamics of SARSCoV-2 through the postpandemic period. Science eabb5793. doi:10.1126/science.abb5793

Klein, N., 2007. The Shock Doctrine: The Rise of Disaster Capitalism. Knopf Canada.

Kluth, A., 2020. This Pandemic Will Lead to Social Revolutions. Bloomberg Opinion.

Kuhn, T.S., 1962. The Structure of Scientific Revolutions, 1st ed. University of Chicago Press.

Laker, L., 2020. World cities turn their streets over to walkers and cyclists. The Guardian.

Lawrence, L., 2001. The future of ideas. Michigan: Random House.

Lederer, E.M., 2020. Crime Rates Plummet Around the World as the Coronavirus Keeps People Inside. TIME.

Lehman, J., 2019. A brief explanation of the Overton Window [WWW Document]. https://www.mackinac.org/OvertonWindow.

Litt, J.S., Schmiege, S.J., Hale, J.W., Buchenau, M., Sancar, F., 2015. Exploring ecological, emotional and social levers of self-rated health for urban gardeners and non-gardeners: A path analysis. Social Science \& Medicine 144, 1-8. doi:https://doi.org/10.1016/j.socscimed.2015.09.004

Loftstrom, M., Martin, B., 2020. COVID-19 and Crime in Major California Cities. Public Policy Institute of California.

Luisa Martin, R., 2014. Occupy: The spatial dynamics of discourse in global protest movements. Journal of Language and Politics 13, 583-598. doi:10.1075/jlp.13.4.01mar

Luneke, A., 2015. Inseguridad ciudadana y diferenciación social en el nivel microbarrial: el caso del sector Santo Tomás, Santiago de Chile. EURE - Revista de Esudios Urbanos Regionales 42.

Lydon, M., Garcia, A., 2015. Tactical Urbanism. Island Press, Washington, DC.

Markusen, A., 2020. Will COVID-19 drive us farther apart, or bring us together? Will we all move away from each other? Not likely. [WWW Document]. Minnesota Reformer. URL https://minnesotareformer.com/2020/04/07/will-covid-19-virusdrive-us-farther-apart-or-bring-us-together/ (accessed 4.8.20).

Millan Lombrana, L., Roston, E., 2020. With Humans in Hiding, Animals Take Back the World. Bloomberg Green.

NASA, 2020. Airborne nitrogen dioxide plummets over China. National Aeronautics and Space Administration. NASA: Earth Observatory.

Nieuwenhuijsen, M., Khreis, H., 2019. Integrating Human Health into the Urban Development and Transport Planning Agenda: A Summary and Final Conclusions, in: Nieuwenhuijsen, M.J., Khreis, H. (Eds.), Integrating Human Health into Urban and Transport Planning. Springer, pp. 707-718. doi:10.1007/978-3-319-74983-9

Nieuwenhuijsen, M., Khreis, H., Verlinghieri, E., Mueller, N., Rojas-Rueda, D., 2019. The Role of Health Impact Assessment for Shaping Policies and Making Cities Healthier, in: Integrating Human Health into Urban and Transport Planning. 
Springer, pp. 609-624. doi:10.1007/978-3-319-74983-9

Nieuwenhuijsen, M.J., 2020. Urban and transport planning pathways to carbon neutral, liveable and healthy cities; A review of the current evidence. Environment International 105661. doi:https://doi.org/10.1016/j.envint.2020.105661

Nieuwenhuijsen, M.J., 2016. Urban and transport planning, environmental exposures and health-new concepts, methods and tools to improve health in cities. Environmental Health 15, S38. doi:10.1186/s12940-016-0108-1

Null, S., Smith, H., 2020. COVID-19 Could Affect Cities for Years. Here Are 4 Ways They're Coping Now. TheCityFix: World Resource Institute (WRI).

Ortiz Escalante, S., Gutiérrez Valdivia, B., 2015. Planning from below: using feminist participatory methods to increase women's participation in urban planning. Gender \& Development 23, 113-126. doi:10.1080/13552074.2015.1014206

Özgen, N., 2014. Power-identity and city squares: A sociopolitic geography analysis. Urban and Urbanization $228-241$.

Polko, A., 2010. Public space development in the context of urban and regional resilience. Cambridge Journal of Regions, Economy and Society 3.

Public Health Scotland, 2019. The Place Standard Tool [WWW Document]. The Place Standard Tool. URL http://www.healthscotland.scot/health-inequalities/impact-of-social-and-physical-environments/place/the-placestandard-tool

Pugalis, L., 2009. The culture and economics of urban public space design: Public and professional perceptions. Urban Design International 14, 215-230. doi:10.1057/udi.2009.23

Roberts, D., 2020. How to make a city livable during lockdown. Vox.

Rojas-Rueda, D., Nieuwenhuijsen, M.J., Gascon, M., Perez-Leon, D., Mudu, P., 2019. Green spaces and mortality: a systematic review and meta-analysis of cohort studies. The Lancet Planetary Health 3, e469-e477. doi:10.1016/S2542-5196(19)30215-3

Rosel, L., 2020. Josep Bohigas: "El confinament fa que ens replantegem la manera de relacionar-nos amb la família, els veïns i la ciutat". ARA.

Rowe, G., 2004. Evaluating Public-Participation Exercises: A Research Agenda. Science, Technology \& Human Values 29, 512-556. doi:10.1177/0162243903259197

Roy, A., 2011. Slumdog Cities: Rethinking Subaltern Urbanism. International Journal of Urban and Regional Research 23, 15-24. doi:10.1111/j.1468-2427.2011.01051.x

Rupprecht, C.D.D., Byrne, J.A., 2014. Informal urban greenspace: A typology and trilingual systematic review of its role for urban residents and trends in the literature. Urban Forestry \& Urban Greening 13, 597-611.

Ryus, P., Ferguson, E., Laustsen, K.M., Schneider, R.J., Proulx, F.R., Hull, T., Miranda-Moreno, L., 2016. Guidebook on Pedestrian and Bicycle Volume Data Collection, Guidebook on Pedestrian and Bicycle Volume Data Collection. The National Academies Press, Washington DC. doi:10.17226/22223

Cvejić, R., Eler, K., Pintar, M., Železnikar, Š., Haase, D., Kabisch, N., Strohbach, M., 2015. A Typology of Urban Green Spaces, Ecosystem Provisioning Services and Demands.

DiNardo, K., 2019. The green revolution spreading across our rooftops. The New York Times.

EFE, 2020. Milán le quitará al coche $35 \mathrm{~km}$ de carriles para dárselos a la bici y el peatón. El Periódico. 21 April.

Francis, L.., Jensen, M., 2017. Benefits of green roofs: A systmatic review of the evidence for three ecosystem services. Urban Forestry \& Urban Greening 28, 167-176.

Gehl Institute, 2017. The Open Public Life Data Protocol. New York, NY.

Gehl, J., 2013. Cities for people. Island Press.

Gehl, J., Svarre, B., 2013. How To Study Public Life, How To Study Public Life. Island Press, Washington DC. doi:10.5822/978-1-61091-525-0_1

Hardiman, J., 2020. 20,000 Tourists Flock To Chinese National Park After Free Entry Offered [WWW Document]. ladbible.com. URL https://www.ladbible.com/news/news-20000-tourists-flock-to-chinese-national-park-after-freeentry-offer-20200406

Lydon, M., Garcia, A., 2015. Tactical Urbanism. Island Press, Washington, DC.

Millan Lombrana, L., Roston, E., 2020. With Humans in Hiding, Animals Take Back the World. Bloomberg Green.

Null, S., Smith, H., 2020. COVID-19 Could Affect Cities for Years. Here Are 4 Ways They're Coping Now. TheCityFix: World Resource Institute (WRI).

Rosel, L., 2020. Josep Bohigas: "El confinament fa que ens replantegem la manera de relacionar-nos amb la família, els veïns i la ciutat". ARA.

Rueda, S., 2019. Superblocks for the Design of New Cities and Renovation of Existing Ones: Barcelona's Case, in: Nieuwenhuijsen, M., Khreis, H. (Eds.), Integrating Human Health into Urban and Transport Planning. Springer, pp. 135-153. doi:10.1007/978-3-319-74983-9

Samuelsson, K., Barthel, S., Colding, J., Vetenskapsakademien, K., Giusti, M., 2020. Urban nature as a source of resilience during social distancing amidst the coronavirus pandemic. Research Gate Pre-print. doi:10.31219/osf.io/3wx5a

Sennett, R., 2018. Building and Dwelling: Ethics for the City. Penguin Random House, London, UK.

Speranza, P., 2018. A human-scaled GIS: measuring and visualizing social interaction in Barcelona's Superilles. Journal of Urbanism 11, 41-62. doi:10.1080/17549175.2017.1341426

TUMI, 2020. Fighting Corona in Transport [WWW Document]. Corona Transport Knowledge Platform. URL https://www.transformative-mobility.org/corona (accessed 4.18.20).

Zografos, C., Klause, K.A., Connolly, J.J.T., Anguelovski, I., 2020. The everyday politics of urban transformational adaptation: Struggles for authority and the Barcelona superblock project. Cities. doi:10.1016/j.cities.2020.102613

Sadik-Kahn, J., Solomonow, S., 2017. Streetfight: Handbook for an urban revolution. Penguin. 
Saelens, B.E., Sallis, J.F., Frank, L.D., 2003. Environmental correlates of walking and cycling: Findings from the transportation, urban design, and planning literatures. Annals of Behavioral Medicine 25, 80-91. doi:10.1207/S15324796ABM2502_03

Salganik, M.J., 2019. Bit by bit: Social research in the digital age. Princeton University Press.

Sandford, A., 2020. Coronavirus: Half of humanity now on lockdown as 90 countries call for confinement. Euronews.

Sanyé-Mengual, E., Anguelovski, I., Oliver-Solà, J., Montero, J.I., Rieradevall, J., 2016. Resolving differing stakeholder perceptions of urban rooftop farming in Mediterranean cities: promoting food production as a driver for innovative forms of urban agriculture. Agriculture and Human Values 33, 101-120. doi:10.1007/s10460-015-9594-y

Schlack Fuhrmann, E., Hidalgo Cepeda, N., Villarroel, K., Arce, M., Fariña, C., 2018. Tres tipos de comercio. Tres maneras de influenciar la esfera pública de los barrios. Revista INVI 33, 89-122.

Sennett, R., 2018. Building and Dwelling: Ethics for the City. Penguin Random House, London, UK.

Solà-Morales, M., 2008. Ten Lessons on Barcelona, 2nd Editio. ed. Col.legi d'Arquitectes de Catalunya, Barcelona.

Talen, E., 2012. City rules : how regulations affect urban form. Island Press.

The Economist, 2020. App-based contact tracing may help countries get out of lockdown. The Economist.

Toderian, B., 2014. Let's Make Sticky Streets for People! Planetizen https://www.planetizen.com/node/69454.

Topham, G., 2020. London pedestrians and cyclists may get more space on roads.

Townsend, M., 2020. Revealed: surge in domestic violence during Covid-19 crisis | Society | The Guardian. The Guardian.

TUMI, 2020. Fighting Corona in Transport [WWW Document]. Corona Transport Knowledge Platform. URL https://www.transformative-mobility.org/corona (accessed 4.18.20).

UNOHCR, 2020. COVID-19: States should not abuse emergency measures to suppress human rights - UN experts. OHCHR.

Vaccotti, L., 2017. Migraciones e informalidad urbana. Dinámicas contemporáneas de la exclusión y la inclusión en Buenos Aires. EURE - Revista de Esudios Urbanos Regionales 43.

Valentino-DeVries, Lu, D., Dance, G.J.X., 2020. Location Data Says It All: Staying at Home During Coronavirus Is a Luxury. The New York Times.

van den Bosch, M., Ode Sang, 2017. Urban natural environments as nature-based solutions for improved public health - A systematic review of reviews. Environmental Research 158, 373-384. doi:10.1016/j.envres.2017.05.040

van der Berg, R., 2020. How Will COVID-19 Affect Urban Planning? TheCityFix.

Velarde, M.D., Fry, G., Tveit, M., 2007. Health effects of viewing landscapes - Landscape types in environmental psychology. Urban Forestry and Urban Greening 6, 199-212. doi:10.1016/j.ufug.2007.07.001

Vicuña, M., Orellana, A., Trufello, R., Moreno, D., 2019. Integración urbana y calidad de vida: disyuntivas en contextos metropolitanos. Revista INVI 34, 17-47.

Villagomez, E., 2018. The laws of settlements: 54 laws underlying settlements across scale and culture. Independently published.

Wertheim-Heck, S., 2020. The impact of the COVID-19 lockdown on the diets of Hanoi's urban poor | International Institute for Environment and Development.

WHO, 2020. Global Surveillance for human infection with coronavirus disease (COVID-19), Interim Guidance.

Whyte, W., 1980. The Social Life of Small Urban Spaces. Project for Public Spaces, New York, NY.

Wray, S., 2020. Bogotá expands bike lanes to curb coronavirus spread. SmartCitiesWorld. 